\title{
The production and partial characterization of a monoclonal IgG antibody specific for moulds belonging to the order Mucorales
}

\author{
Gerhard A. De Ruiter, ${ }^{1}$ Andrea W. Van Bruggen-van der Lugt, ${ }^{1}$ Wilhelm Bos, ${ }^{2}$ \\ Servé H. W. Notermans, ${ }^{3}$ Frank M. Rombouts ${ }^{*}$ and Harmen Hofstra ${ }^{2}$ \\ ${ }^{1}$ Wageningen Agricultural University, Department of Food Science, PO Box 8129, 6700 EV Wageningen, \\ The Netherlands \\ ${ }^{2}$ Institute for Biotechnology and Chemistry, TNO-Food Division, PO Box 360, 3700 AJ Zeist, The Netherlands \\ ${ }^{3}$ National Institute of Public Health and Environmental Protection, Laboratory for Water and Food Microbiology, \\ PO Box 1, 3720 BA Bilthoven, The Netherlands
}

(Received 11 December 1992; revised 22 February 1993; accepted 8 March 1993)

\begin{abstract}
A monoclonal antibody (mAb) was raised against extracellular polysaccharides from Mucor racemosus after intrasplenic immunization of mice. An indirect ELISA and a dot-blot assay were developed with this mAb. The IgG antibody was found to be very specific for all mould species tested belonging to the order of Mucorales, except species belonging to the genus Mortierella sensu stricto. No cross-reactions were observed with other moulds or yeasts. The immunoreactivity of the polysaccharides of these moulds with this $\mathrm{mAb}$ is based on carbohydrate epitopes, in which fucose residues probably play an important role. The mAb may be suited for specific detection of species of the genera Mucor, Rhizopus, Rhizomucor, Thamnidium, Absidia, Syncephalastrum and species belonging to the Mortierella isabellina group in food, and possibly for diagnosis of mucormycosis in humans.
\end{abstract}

\section{Introduction}

Moulds belonging to the order Mucorales (Zygomycetes), including the genera Mucor, Rhizopus, Rhizomucor, Syncephalastrum, Absidia and Thamnidium, are found in many parts of the world. Some species are important as casual agents of mucormycosis in man (Sugar, 1992). Some are pathogenic for crop plants and many can cause food spoilage resulting in a huge economic loss (Pitt \& Hocking, 1985). In general, the presence of moulds in food is often associated with loss of quality; therefore early detection of moulds is important.

Modern detection methods in food mycology are based on the recognition of fungal antigenic polysaccharides by specific immunoassays (Notermans \& Heuvelman, 1985; De Ruiter et al., 1993b). Recently, the

*Author for correspondence. Tel. 8370 83786; fax 837084893 .

Abbreviations: mAb, monoclonal antibody; $\mathrm{pAb}$, polyclonal antibody; EPS, extracellular polysaccharide; PBS, phosphate-buffered saline; PBST, PBS with 0.05\% Tween 20; NC, nitrocellulose; DEAE I, fraction 1 of a DEAE anion-exchange column; TFA, trifluoroacetic acid. development of a specific ELISA for species of Mucorales was described and successfully used to detect these species in food (De Ruiter et al., 1992a).

Polyclonal IgG antibodies (pAbs) raised in rabbits against the extracellular polysaccharides (EPSs) of Mucor racemosus were recently characterized as being almost specific for moulds belonging to the order of Mucorales, as cross-reactivity was only observed towards the yeast Pichia membranaefaciens but not to any other species of mould or yeast tested (De Ruiter et al., 1992d). To enhance the specificity and the feasibility to commercialize specific test kits, monoclonal antibodies (mAbs) are necessary (Dewey, 1992). Recently, mAbs specific for Penicillium, Aspergillus and Botrytis species have been described and used in the analysis of foods and feeds (Dewey et al., 1990; Stynen et al., 1992; Bossi \& Dewey, 1992) but until now, no mAbs specific for mould species belonging to the order Mucorales have been reported.

The EPSs of Mucorales consist mainly of carbohydrates and protein, with fucose, galactose, mannose, glucose and glucuronic acid as the main sugar residues (Bartnicki-García \& Reyes, 1968; Miyazaki et al., 1980; De Ruiter et al., $1991 a, b)$. Glucuronic acid is present as $\beta(1-4)$-linked D-glucuronic acid polymers, an important 
structural entity of these EPSs (De Ruiter $e t a l ., 1992 b$ ). Furthermore these EPS preparations contain 2-Omethyl-mannose residues, which are immunoreactive with polyclonal rabbit antibodies (G. A. De Ruiter, A. W. Van Bruggen-van der Lugt, P. Smid, P. Mischnick, J. H. Van Boom \& F. M. Rombouts, unpublished data).

In the present report, we describe the production of a monoclonal IgG antibody against EPS of Mucor racemosus and the development of an indirect ELISA and a dot-blot assay based on this antibody. These assays were used to determine the specificity of the $\mathrm{mAb}$ and to compare its activity with that of polyclonal IgG antibodies. Furthermore, the structure of the epitopes of the antigenic EPSs reactive with this mAb was studied by periodate treatment, by specific enzymic degradation and by partial acid hydrolysis.

\section{Methods}

Extracellular polysaccharides. EPSs of 29 strains of moulds (Table 1) were produced, isolated and purified by ethanol precipitation as described by De Ruiter $e$ t al. (1991 b). Also, 39 yeast strains were tested in this study as described by De Ruiter et al. (1992d).

Preparation of hybridomas. Mice (BALB/c, female, 6 weeks old) were immunized by intrasplenic injection of $50 \mu \mathrm{g}$ EPS from Mucor racemosus in PBS (70 mM-sodium phosphate, $\mathrm{pH} 7 \cdot 2,150 \mathrm{~mm}-\mathrm{NaCl}$ ) according to the method of Spitz (1986). Spleen cells were collected and fused with cells of the mouse myeloma cell line $\mathrm{P} 3 \times 63 \mathrm{Ag} 8.653$ (ATCC: CRL 1580) according to the polyethylene glycol method as described by De St Groth \& Scheidegger (1980).

The fused cells were distributed at a density of $1 \times 10^{5}$ viable cells per well in 96-well sterile culture trays (Intermed Nunclon), and tested for antibody production by indirect ELISA as described below. Wells positive for antibody production were twice subcloned and expanded by transferring them to 24-well sterile cell culture plates, and subsequently expanded further to $50 \mathrm{ml}$ flasks and $500 \mathrm{ml}$ culture flasks (Davis et al., 1982). Cells in exponential growth were frozen by control rate freezing in Dulbecco's modified Eagle's medium (Gibco) with $10 \%(\mathrm{v} / \mathrm{v})$ dimethyl sulphoxide (DMSO) and stored in the vapour phase of a liquid nitrogen freezer.

Determination of the immunoglobulin subclass and concentration of the $m A b$. Isotyping of the mAbs produced by these lines was performed using a mouse $\mathrm{mAb}$ isotyping kit (Life Technologies) according to the supplier's instructions.

The concentration of $\mathrm{mAb}$ IgG in the supernatant was determined using an ELISA, by coating $100 \mu \mathrm{l}$ of a $10 \mu \mathrm{g} \mathrm{ml}^{-1}$ solution of goat antimouse IgG+ IgM (4153; Tago Inc.) in PBS for $3 \mathrm{~h}$ at $37^{\circ} \mathrm{C}$. The microtitre plates were washed three times with PBS containing $0.05 \%$ (w/v) Tween 20 (PBST). Next, the wells were filled with $50 \mu 1$ PBST, $100 \mu \mathrm{l}$ of the mAb-containing supernatant was added to the first well and subsequently diluted serially by transferring $50 \mu \mathrm{l}$ to the next well each time. After incubation for $1 \mathrm{~h}$ at $37^{\circ} \mathrm{C}$, the plates were washed three times with PBST, and $100 \mu$ peroxidase conjugated to goat antimouse IgG (Zymed Laboratories) was added to each well $(1: 2000$ in PBST with $1 \%, v / v$, bovine calf serum). Following incubation for $1 \mathrm{~h}$ at $37^{\circ} \mathrm{C}$, the plates were washed three times with PBST and incubated with $100 \mu \mathrm{l}$ of $3,3^{\prime}, 5,5^{\prime}$-tetramethylbenzidine in DMSO containing
$\mathrm{H}_{2} \mathrm{O}_{2}$ prepared according to Bos et al. (1981). The peroxidase reaction was stopped after incubation for $30 \mathrm{~min}$ at $25^{\circ} \mathrm{C}$ by adding $50 \mu 12 \mathrm{M}$ $\mathrm{H}_{2} \mathrm{SO}_{4}$ to each well. The absorbance of the yellow colour was measured spectrophotometrically at $450 \mathrm{~nm}$. The concentration of mAb IgG1 was determined by comparing the ELISA titration curve of the supernatant with those of a sample of mouse IgG1 (Southern Biotechnology Associates), which was diluted from a $1.0 \mathrm{mg} \mathrm{m}^{-1}$ solution on the same microtitre plate for calibration.

Indirect ELISA for polyclonal and monoclonal IgG. Polyclonal IgG antibodies (pAb 1000/1201) were obtained by immunization of rabbits with EPS isolated from Mucor racemosus as described by Notermans \& Heuvelman (1985). The IgG fraction of the serum was purified using selective precipitation with octanoic acid as described by Steinbuch \& Audran (1969). ELISA was carried out essentially as described by Notermans et al. (1988). For this, wells of polyvinyl chloride microtitre plates (Dynatech) were coated with $100 \mu \mathrm{l}$ of a $5 \mu \mathrm{g} \mathrm{ml}^{-1}$ preparation of EPS derived from Mucor racemosus in PBS for $16 \mathrm{~h}$ at $25^{\circ} \mathrm{C}$. After washing three times in PBST, $100 \mu \mathrm{l}$ of different dilutions of either the $\mathrm{pAb}$ diluted in PBS containing $1 \%(\mathrm{w} / \mathrm{v})$ bovine serum albumin (BSA) or the $\mathrm{mAb}$ diluted in PBS were added and incubated for $1.5 \mathrm{~h}$ at $25^{\circ} \mathrm{C}$. In the pAb-ELISA, peroxidase-conjugated goat anti-rabbit antibodies (Sigma A-8275) were used and in case of the mAb-ELISA, peroxidaseconjugated goat anti-mouse antibodies (Sigma A-4416) were used. The respective conjugates were diluted 1000 -fold in PBST containing $1 \%$ $(\mathrm{w} / \mathrm{v}) \mathrm{BSA}$ and $100 \mu \mathrm{l}$ was subsequently added to each well. Incubation was performed for $1.5 \mathrm{~h}$ at $25^{\circ} \mathrm{C}$ then the plates were rinsed three times with PBST. Finally, $100 \mu 1$ of 3,3',5,5'-tetramethylbenzidine substrate was added as described above. The ELISA reactivity was expressed as the titre, defined as the reciprocal dilution of a solution of $10 \mu \mathrm{g} \mathrm{m}^{-1}$ antibody just giving a positive reaction, i.e. an absorbance $\geqslant 0 \cdot 1$ above that of a blank.

Dot-blot analysis. Antigenic fungal polysaccharides were bound to nitrocellulose membranes (NC; $0.1 \mu \mathrm{m}$; Schleicher \& Schuell) by spotting droplets $(2 \mu \mathrm{l})$ of $50 \mathrm{mg} \mathrm{m}^{-1}$ preparations of various EPSs in PBS. After the antigen had been allowed to air-dry onto the membrane for $30 \mathrm{~min}$ at $25^{\circ} \mathrm{C}$, it was blocked with a $0 \cdot 1 \%(\mathrm{w} / \mathrm{v})$ solution of sodium caseinate (DMV Campina) in PBS for $1 \mathrm{~h}$ at $25^{\circ} \mathrm{C}$. The resulting membrane was then exposed to solutions of either the $\mathrm{mAb}$ 12.8 or the pAb 1000/1201 in PBS containing $0.5 \%$ (w/v) BSA. Prior to use, the $\mathrm{mAb}$-containing supernatant was diluted ten times while a $\mathrm{pAb}$ solution with a similar concentration of protein was used. Both were incubated for $16 \mathrm{~h}$ at $25^{\circ} \mathrm{C}$. After washing the membrane three times with PBST ( 2 min each wash), the nitrocellulose membranes were incubated for $1.5 \mathrm{~h}$ at $25^{\circ} \mathrm{C}$ with the anti-mouse or anti-rabbit antibodies conjugated with peroxidase as described above for the indirect ELISAs. Finally, the nitrocellulose membranes were washed (PBST, $3 \times 2 \mathrm{~min}$ ) and coloured by dipping for $30 \mathrm{~min}$ in a ready-to-use substrate solution of 4-chloro-1-naphthol (PrestoSol BL; Janssen Biotech) which is converted by the peroxidase enzyme to a compound with a dense blue colour. The optical density (OD) of the spots was measured using a laser densitometer (Computing densitometer 300A, Molecular Dynamics) equipped with a helium-neon laser $(\lambda 672 \mathrm{~nm})$ using ImageQuant 3.15 software. The values were corrected by subtracting the $\mathrm{OD}$ of the nitrocellulose paper alone.

Periodate oxidation of the antigens. A polysaccharide sample $(5 \mathrm{mg})$ was treated for $24 \mathrm{~h}$ at $4{ }^{\circ} \mathrm{C}$ with $2 \mathrm{ml}$ of a solution of $50 \mathrm{~mm}-\mathrm{NaIO}_{4}$ in $0.25 \mathrm{M}$-formic acid, adjusted to $\mathrm{pH} 3.7$ with $1 \mathrm{M}-\mathrm{NaOH}$. The excess periodate was inactivated by the addition of $400 \mu 1$ 1,2-ethane diol and incubation for $1 \mathrm{~h}$. The oxidized polysaccharide was reduced by adding $4 \mathrm{ml} \mathrm{0.5} \mathrm{M}$-sodium borohydride in $1 \mathrm{M}-\mathrm{NaOH}$ and incubating for $16 \mathrm{~h}$ at $25^{\circ} \mathrm{C}$. The mixture was cooled on ice and $300 \mu \mathrm{l}$ acetic acid was added twice to destroy the excess $\mathrm{NaBH}_{4}$. The polysaccharide was recovered after overnight dialysis against running tap-water followed 
by dialysis against several batches of distilled water for $24 \mathrm{~h}$, and finally lyophilized.

Enzyme treatment of the EPSs. An exo- $\alpha$-D-mannanase was purified from an enzyme preparation of the mould Trichoderma harzianum, and an $\alpha$-mannosidase (EC 3 2.1.24) isolated from Jack beans (Canavalia ensiformis) was obtained from Sigma (M 7257), and used without further purification. Ten microlitres $2 \mathrm{M}$-sodium acetate buffer ( $\mathrm{pH} 5 \cdot 0$ ) was added to $175 \mu \mathrm{l}$ EPS solution $\left(1 \mathrm{mg} \mathrm{ml}^{-1}\right)$ and $65 \mu \mathrm{l}(0.75 \mathrm{mU})$ exo$\alpha$-D-mannanase or, alternatively, $0.75 \mathrm{mU} \alpha$-mannosidase. Incubation was performed at $30^{\circ} \mathrm{C}$ for $16 \mathrm{~h}$ and the enzymes were subsequently inactivated by heat treatment $\left(5 \mathrm{~min}, 100^{\circ} \mathrm{C}\right)$. The immunoreactivities of the native and the different enzyme-treated EPSs were measured using indirect ELISA as described above.

Separation of the EPSs. The EPSs were separated by differences in charge into three different fractions by anion-exchange chromatography using a DEAE-Sepharose CL-6B column (Pharmacia) as described by De Ruiter et al. $(1991 b)$. The fractions were designated as DEAE I, DEAE II and DEAE III according to the order of elution from this column using a gradient of 0.05-1 M-sodium acetate buffer (pH 5.0).

Partial acid hydrolysis of the antigens. Partial acid hydrolysis of the immunoreactive polysaccharide fraction of $M$. racemosus was performed on $250 \mu \mathrm{g}$ material in a screw-cap tube. Solutions of different concentrations of trifluoroacetic acid (TFA) in distilled water were prepared in the range $0.5-250 \mathrm{~mm}$. An aliquot $(0.5 \mathrm{ml})$ of the respective TFA solution was added to each tube which was subsequently closed, mixed and heated in an oil bath at different temperatures. After incubation for $1 \mathrm{~h}$ the tubes were cooled and the content was evaporated to dryness by a stream of air $\left(25^{\circ} \mathrm{C}\right)$. Distilled water $(100 \mu \mathrm{l})$ was added to each tube and mixed thoroughly and finally the mixture was transferred to an HPLC vial.

The inhibitory capacity of the resulting mixture was determined in the inhibition ELISA as described above. The amount of liberated monosaccharide residues was estimated by high-performance anionexchange chromatography using a Dionex Bio-LC high-performance liquid chromatography system (Dionex) equipped with a CarboPac PA 1 column $(4 \times 250 \mathrm{~mm})$ and pulsed-amperometric detection using a gold working electrode and an $\mathrm{Ag}-\mathrm{AgCl}$ reference electrode as described by De Ruiter et al. (1992c).

\section{Results}

Production of a mAb against EPS from Mucor racemosus

Fusion of spleen cells of mice immunized intrasplenically with EPS from the mould Mucor racemosus and 8azaguanine-resistant myeloma $\mathrm{P} 3 \times 63 . \mathrm{Ag} 8$ cells, yielded 490 hybridomas of which 9 were reactive with EPS of Mucor racemosus. The hybridomas were tested for antibody production in the indirect ELISA in which EPS of Mucor racemosus was coated to the microtitre plates. Supernatants from these wells were tested for crossreactivity with EPS preparations from a number of moulds, including representatives of Penicillium, Aspergillus, Fusarium, Botrytis, Alternaria and Cladosporium. Only one of these hybridomas (12.8) showed a strong reaction with EPS from Mucor racemosus and no reaction with EPSs from moulds belonging to other genera. Cells from this well were cloned, and wells positive for growth and antibody production were subcloned once more. The resulting clone (designated $\mathrm{mAb} 12.8$ ) was grown as described and the supernatant was used for all further experiments. mAb 12.8 was typed as IgG of subclass 1 (kappa). The concentration of the IgG1 mAb in the supernatant was

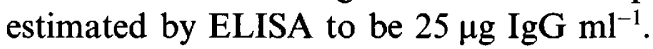

\section{Specificity of $m A b 12.8$}

The specificity of mAb 12.8 was studied by determination of the titres of 29 different EPS preparations of 13 mould genera (Table 1). mAb 12.8 gave a positive immunoreaction with the EPS preparations from all moulds tested belonging to the order Mucorales except species of the genus Mortierella senu stricto, which includes the species reticulata, hyalina and polycephala (De Ruiter $e t$ $a l ., 1993 a$ ). No reactivity was observed with other mould species often occurring in food such as Penicillium, Aspergillus and Fusarium. Furthermore, 39 yeast species belonging to 20 different genera (see Table 1 from De Ruiter et al., 1992d) were tested for cross-reactivity with $\mathrm{mAb}$ 12.8. These yeasts did not show any reactivity. Even the yeast Pichia membranaefaciens, which gave a clear positive immunoreaction with pAb 1000/1201, did not show cross-reactivity with mAb 12.8 (Table 1).

\section{Reactivity of polyclonal and monoclonal antibodies raised against $M$. racemosus}

The reactivity of $\mathrm{mAb} 12.8$ was compared with the reactivity of pAb 1000/1201 antibodies raised in rabbits against the same EPS preparation of $M$. racemosus as described previously (De Ruiter et al., 1992d). This was performed by determination of the titration curves in the respective indirect ELISAs after binding $5 \mu \mathrm{g} \mathrm{m}^{-1}$ of the same EPS preparation of $M$. racemosus to the wall of microtitre plates. As shown in Fig. 1, both pAb $1000 / 1201$ and $\mathrm{mAb} 12.8$ were reactive with this EPS preparation although slightly higher extinctions could be obtained with the pAbs. A more detailed comparison of the selectivity of each antibody was made by determination of the titres using different EPS preparations obtained from moulds belonging to Mucorales listed in Table 1. Both antibodies reacted with all EPSs but their reactivity differed significantly. pAb 1000/1201 gave the highest reactivity with the EPS preparation of Mucor circinelloides whereas mAb 12.8 gave only a weak immunoreaction. In contrast, the EPSs from Rhizomucor species showed a much higher reaction with $\mathrm{mAb} 12.8$ than with pAb $1000 / 1201$. To exclude the possibility that these differences in reactivity were caused by differences 
Table 1. Reactivity of $m A b 12.8$ and pAb 1000/1201 raised against the EPS of Mucor racemosus with EPSs of different moulds

Microtitre plates were coated with $5 \mu \mathrm{g} \mathrm{ml}^{-1}$ of the respective EPS preparation. ELISA reactivity is expressed as the titre, defined as the reciprocal dilution of a solution of $10 \mu \mathrm{g} \mathrm{ml}^{-1}$ antibody just giving a positive reaction.,$- \leqslant 10 ;+, 10<$ titre $\leqslant 100 ;++, 100<$ titre $\leqslant$ $1000 ;+++$, titre $>1000$. Experiments were carried out in triplicate.

\begin{tabular}{|c|c|c|}
\hline \multirow[b]{2}{*}{ Mould strain } & \multicolumn{2}{|c|}{ Indirect ELISA titre } \\
\hline & $\begin{array}{c}\mathrm{mAb} \\
12.8\end{array}$ & $\begin{array}{c}\text { pAb } \\
1000 / 1201\end{array}$ \\
\hline Mucor racemosus Fres., CBS 222.81 & $+t+$ & +++ \\
\hline Mucor hiemalis Wehmer CBS 201.28 & +++ & ++ \\
\hline Mucor circinelloides van Tieghem RIVM M 40 & + & +++ \\
\hline Rhizopus stolonifer (Ehrenb.) Lind CBS 609.82 & ++ & ++ \\
\hline Rhizopus oryzae Went \& Prinsen Geerlings LU 581 & ++ & ++ \\
\hline Rhizomucor pusillus (Lindt) Schipper CBS 432.78 & +++ & ++ \\
\hline Rhizomucor miehei (Cooney \& Emerson) Schipper CBS 371.71 & +++ & ++ \\
\hline Absidia corymbifera (Cohn) Sacc. \& Trotter LU 017 & + & ++ \\
\hline Thamnidium elegans Link CBS 342.55 & + & ++ \\
\hline Syncephalastrum racemosum Cohn CBS 443.59 & + & ++ \\
\hline Mortierella reticulata van Tieghem CBS 452.74 & - & - \\
\hline Mortierella hyalina (Harz) W. Gams CBS 654.68 & - & - \\
\hline Mortierella polycephala Coemans CBS 327.72 & - & - \\
\hline Mortierella roseonana W. Gams CBS 473.74 & ++ & ++ \\
\hline Mortierella nana Linnem, CBS 730.70 & ++ & ++ \\
\hline $\begin{array}{l}\text { Mortierella ramanniana (Möller) Linnem. } \\
\text { var. ramanniana CBS } 243.58\end{array}$ & ++ & + \\
\hline Mortierella ovata Yip CBS 499.82 & + & + \\
\hline Mortierella isabellina Oudem. CBS 560.63 & + & + \\
\hline Penicillium citrinum Thom CBS 117.64 & - & - \\
\hline Penicillium dierckxi Biourge RIVM M 90 & - & - \\
\hline Penicillium aurantiogriseum Dierckx CBS 342.51 & - & - \\
\hline Penicillium digitatum Sacc. RIVM M58 & - & - \\
\hline Aspergillus fumigatus Fres. RIVM M3 & - & - \\
\hline Aspergillus niger van Tieghem CBS 553.65 & - & - \\
\hline Fusarium solani (Mart.) Sacc. CBS 165.87 & - & - \\
\hline Fusarium poae (Peck) Wollenweber CBS 446.67 & - & - \\
\hline Alternaria alternata $(\mathrm{Fr}$.$) Keissler RIVM M 13$ & - & - \\
\hline Botrytis cinerea Pers. RIVM M 17 & - & - \\
\hline $\begin{array}{l}\text { Cladosporium cladosporioides (Fres.) } \\
\text { de Vries CBS } 143.65\end{array}$ & - & - \\
\hline Pichia membranaefaciens (Hansen) Hansen & - & ++ \\
\hline
\end{tabular}

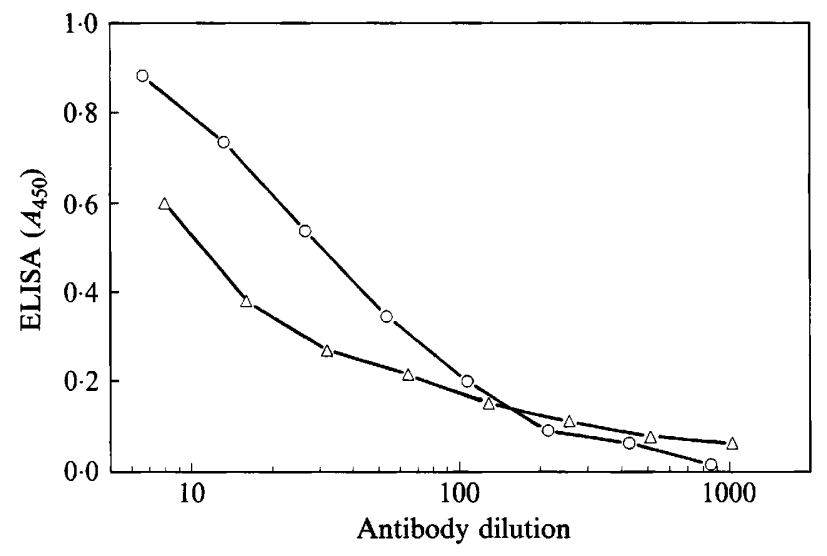

Fig. 1. Titration curves of $\mathrm{mAb} 12.8(\triangle)$ and pAb 1000/1201 (O) in an indirect ELISA coated with a preparation of EPS $\left(5 \mu \mathrm{g} \mathrm{m} l^{-1}\right)$ from Mucor racemosus. The values represent the dilution of a $10 \mu \mathrm{g} \mathrm{ml}^{-1}$ solution of the respective antibodies. in binding properties of the EPS preparations to the wall of the microtitre plates, a dot-blot assay was developed for both the polyclonal and monoclonal antibodies.

\section{Development of a dot-blot assay}

A dot-blot assay in which the polysaccharide antigens were directly bound to nitrocellulose (NC) paper was developed by testing various conditions for binding the EPSs to the NC, using different buffers with $\mathrm{pH}$ values in the range 5-9. Maximum binding was obtained by spotting $2 \mu \mathrm{l}$ droplets containing $100 \mu \mathrm{g}$ EPS in PBS (pH 7.2) followed by air-drying for $30 \mathrm{~min}$. Optimal blocking of the NC was performed with a solution of $0.1 \%(\mathrm{w} / \mathrm{v})$ sodium caseinate. Both BSA and a crude milk protein were not very effective blockers as concentrations of more than $1 \%(\mathrm{w} / \mathrm{v})$ were needed for complete 


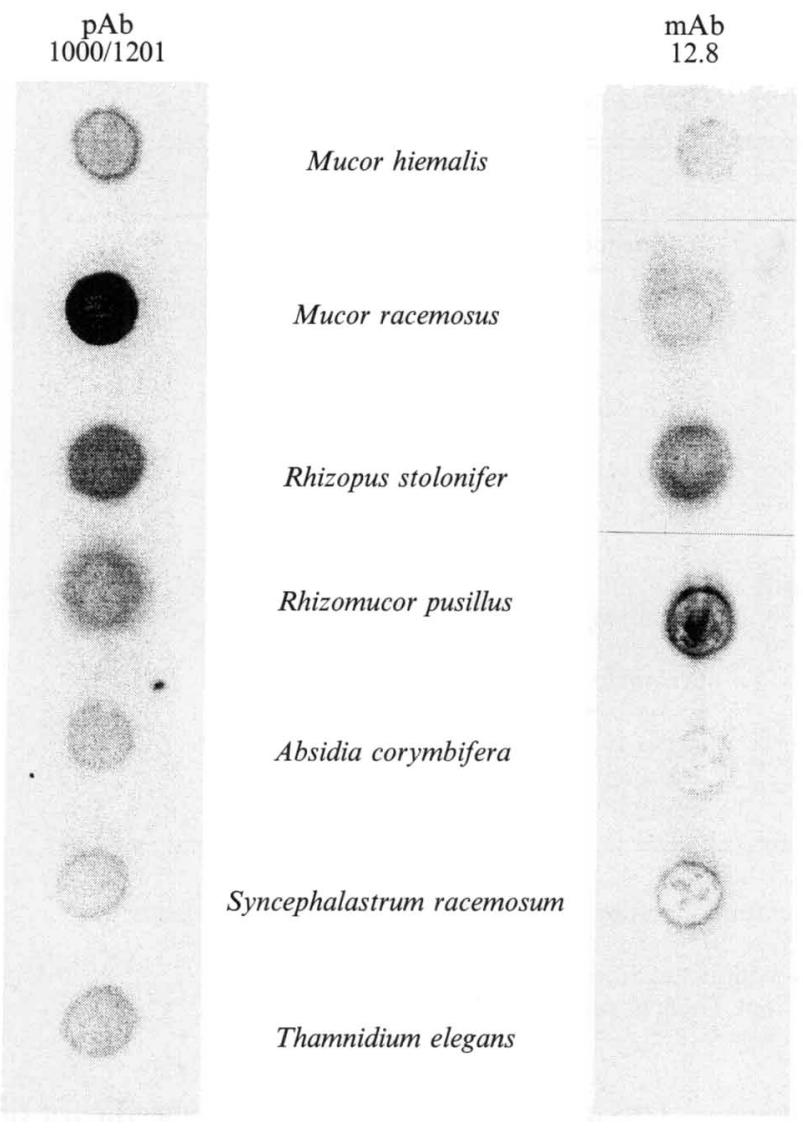

blocking. After washing, the NC was incubated with the respective antibodies in similar concentration and subsequently incubated with the respective peroxidase conjugates. The NC membranes were developed with the 4chloro-1-naphthol substrate, PrestoSol.

The EPS preparations used in this dot-blot assay revealed a difference in reactivity of $\mathrm{mAb} 12.8$ and $\mathrm{pAb}$ $1000 / 1201$ as shown in Fig. 2. EPS from Mucor racemosus gave the strongest immunoreaction with $\mathrm{pAb}$ $1000 / 1201$ whereas Rhizomucor pusillus gave the strongest reaction with mAb 12.8 .

\section{Isolation of the immunoreactive fraction of the EPSs}

The role of the sugar residues in the immunoreactivity of EPSs with the $\mathrm{mAb}$ was studied by periodate oxidation. Mild periodate oxidation, which is reported to be specific for sugar residues containing vicinal - $\mathrm{OH}$ groups, completely destroyed the reactivity of both the pAb and the $\mathrm{mAb}$ with EPSs from Mucorales (Table 2).

The pAbs raised against EPS of $M$. racemosus reacted with two specific polysaccharide fractions: the first (DEAE I) did not bind to a DEAE anion-exchange column; and the second (DEAE II) could be eluted from this column with 200-300 mM buffer salt, as also shown for the EPS of Mucor hiemalis (De Ruiter et al., 1991b). As shown in Table 2, mAb 12.8 did not react with these
Fig. 2. Dot-blot analysis of various EPSs isolated from species belonging to the order Mucorales with $\mathrm{mAb} 12.8$ and $\mathrm{pAb} 1000 / 1201$. After correction for the optical density of the nitrocellulose paper itself, the limits for black were set at $\mathrm{OD} 0.22$ and 0.70 for $\mathrm{mAb} 12.8$ and $\mathrm{pAb}$ $1000 / 1201$, respectively.
pAb-reactive fractions but reacted with the major polysaccharide fraction (DEAE III). This immunoreactive DEAE III fraction was isolated by anionexchange chromatography using $0 \cdot 9-1$ M-sodium acetate buffer, $\mathrm{pH} 5 \cdot 0$. This fraction, sometimes called mucoran, is characteristic of moulds belonging to Mucorales and contains approximately $50 \%$ glucuronic acid (BartnickiGarcía \& Lindberg, 1972; De Ruiter et al. 1991b). Recently, we isolated the $\beta(1-4)$-linked D-glucuronic acid polymeric backbone of this polysaccharide (De Ruiter $e t$ $a l ., 1992 b$ ), but mAb 12.8 was not reactive with this preparation.

\section{Partial determination of the $m A b$ epitopes}

The antigenic determinants of the immunoreactive polysaccharide fraction were partly characterized using specific enzymes and partial acid hydrolysis to degrade the polysaccharide. As shown in Table 2, treatment of various EPSs isolated from species of Mucorales with an exo- $\alpha$-D-mannanase, which is able to degrade specifically the epitopes reactive with pAb $1000 / 1201$, did not degrade the epitopes reactive with mAb 12.8. Treatment of the EPSs with a $\alpha$-mannosidase, which hydrolyses non-reducing terminal mannose residues, did not have any effect on the immunoreactivity of the EPSs with $\mathrm{mAb} 12.8$ and pAb 1000/1201. 
Table 2. Reactivity of $m A b 12.8$ and $p A b$ 1000/1201 IgG antibodies with different fractions of the EPSs from Mucorales and with EPSs subjected to various treatments

\begin{tabular}{|c|c|c|c|c|}
\hline \multirow[b]{2}{*}{ EPS from } & \multirow[b]{2}{*}{ Fraction } & \multirow[b]{2}{*}{ Treatment } & \multicolumn{2}{|c|}{ Indirect ELISA titre* } \\
\hline & & & $\mathrm{mAb}$ & $\mathrm{pAb}$ \\
\hline \multirow[t]{3}{*}{ Mucor racemosus } & DEAE I $\dagger$ & & - & +++ \\
\hline & DEAE II & & - & ++ \\
\hline & DEAE III & & +++ & - \\
\hline \multirow[t]{3}{*}{ Rhizopus stolonifer } & DEAE I & & - & +++ \\
\hline & DEAE II & & - & ++ \\
\hline & DEAE III & & +++ & - \\
\hline \multirow[t]{3}{*}{ Rhizomucor pusillus } & DEAE I & & - & $+t+$ \\
\hline & DEAE II & & - & +++ \\
\hline & DEAE III & & $+t+$ & - \\
\hline Mucor hiemalis & Polyglucuronic acid $\ddagger$ & & - & - \\
\hline Mucor hiemalis & & Periodate oxidation & - & - \\
\hline Rhizopus oryzae & & Periodate oxidation & - & - \\
\hline Absidia corymbifera & & Periodate oxidation & - & - \\
\hline Mucor racemosus & & Exo- $\alpha$-D-mannanase & +++ & - \\
\hline Rhizopus stolonifer & & Exo- $\alpha$-D-mannanase & +++ & - \\
\hline Mucor racemosus & & $\alpha$-Mannosidase & +++ & $+t+$ \\
\hline Rhizopus stolonifer & & $\alpha$-Mannosidase & +++ & +++ \\
\hline
\end{tabular}

* See legend Table 1.

$\dagger$ Fractions of a DEAE anion-exchange chromatography similar to those shown for $M$. hiemalis in Fig. 3 of De Ruiter et al. (1991b).

$\ddagger$ Polymer of $\beta(1-4)$-linked D-glucuronic acid as described in De Ruiter et al. (1992b).

$\S$ Purified from an enzyme preparation from Trichoderma harzianum.

Partial acid hydrolysis was performed on the immunoreactive polysaccharide fraction (DEAE III) using increasing concentrations of TFA. The reaction products were analysed and the inhibitory capacity of the remaining polysaccharide fraction was established by indirect mAb-ELISA. As shown in Table 3, fucose residues were liberated in increasing amounts with the use of up to $5 \mathrm{~mm}$-TFA and heating for $1 \mathrm{~h}$ at $100^{\circ} \mathrm{C}$. This also resulted in a considerable decrease in the inhibitory capacity of the remaining partially hydrolysed immunoreactive polysaccharide. At higher concentrations of acid more fucose and gradually also some galactose, glucose and mannose residues were liberated. The inhibitory capacity of the remaining polysaccharide decreased to only $1 \%$ of the initial inhibitory capacity after hydrolysis with 250 mM-TFA. Additional partial hydrolysis experiments were performed with 5 mM-TFA using different temperatures. These experiments revealed that at $94{ }^{\circ} \mathrm{C}$ approx. $40 \%$ of the inhibitory capacity was abolished, with fucose as the only hydrolysis product (results not shown).

\section{Discussion}

The $\mathrm{mAb}$ raised against EPS isolated from $M$. racemosus was specific for all mould species belonging to the order Mucorales. No cross-reactions were observed with EPSs from mould or yeast species tested other than Mucorales.
This $\mathrm{mAb}$ was found to be more specific for these moulds than the pAbs raised against the same EPS, as the latter showed cross-reactivity with the yeast Pichia membranaefaciens (De Ruiter et al., 1992d). With these antibodies, an indirect ELISA and a dot-blot assay were developed which may be used to detect these mould species.

$\mathrm{mAb} 12.8$ and pAb 1000/1201 differ in their reactivity with the different EPS preparations from Mucorales. $\mathrm{pAb} 1000 / 1201$ reacted best with EPS from Mucor racemosus and $M$. circinelloides whereas $\mathrm{mAb} 12.8$ showed the highest activity towards $M$. racemosus and the Rhizomucor spp. mAb 12.8 and pAb 1000/1201 reacted in a similar way with the EPS preparations obtained from species from the Mortierella isabellina group. This supports the recently described affinity of this group of moulds to the Mucoraceae, while Mortierella sensu stricto falls outside this affinity (De Ruiter et al., 1993a).

The immunological reaction of these fungal carbohydrate antigens with $\mathrm{mAb} 12.8$ is based on carbohydrate epitopes, as mild periodate treatment completely destroyed their antigenic activity. The pAb-reactive fractions were not reactive with $\mathrm{mAb} 12.8$, and the exo$\alpha$-D-mannanase, which specifically degrades the $\mathrm{pAb}$ epitopes, did not have any influence on the immunoreactivity of $\mathrm{mAb} 12.8$. This monoclonal antibody reacted exclusively with the DEAE III fraction containing mucoran. It can be assumed that the antigenicity 
Table 3. Influence of partial hydrolysis of the immunoreactive polysaccharide fraction from Mucor racemosus with TFA $\left(1 \mathrm{~h}, 100^{\circ} \mathrm{C}\right)$ on its capacity to inhibit the reaction between the EPS of $M$. racemosus and $M A b 12.8$ raised against this EPS*

\begin{tabular}{|c|c|c|c|c|c|}
\hline \multirow{2}{*}{$\begin{array}{l}\text { TFA } \\
\text { concn (mM) }\end{array}$} & \multicolumn{4}{|c|}{ Liberated carbohydrate monomers $\dagger$} & \multirow{2}{*}{$\begin{array}{c}\text { Inhibitory } \\
\text { capacity } \\
(\%)\end{array}$} \\
\hline & Fuc & Gal & Man & Glc & \\
\hline 250 & 16 & 10 & 1 & 4 & 1 \\
\hline 50 & 7 & 3 & 0 & 3 & 10 \\
\hline 25 & 5 & 2 & - & 1 & 17 \\
\hline 12.5 & 4 & 1 & - & 1 & 37 \\
\hline 5 & 3 & 0 & - & - & 58 \\
\hline $2 \cdot 5$ & 2 & - & - & - & 75 \\
\hline 1.25 & 1 & - & - & - & 83 \\
\hline 0.5 & 0 & - & - & - & 86 \\
\hline 0 & - & - & - & - & 100 \\
\hline
\end{tabular}

* Values are the average of duplicate experiments.

$\dagger$ Amount (values in $\mu \mathrm{g} ; 0$, present but $<0.5 \mu \mathrm{g}$; - , not present) of carbohydrate monomers liberated during incubation of $250 \mu \mathrm{g}$ of the immunoreactive polysaccharide fraction (DEAE III) with the respective TFA solution, as estimated by high-performance anion-exchange chromatography (De Ruiter et al., 1992c). Abbreviations: Fuc, fucose; Gal, galactose; Man, mannose; Glc, glucose.

\pm Inhibitory capacity of $150 \mu \mathrm{g} \mathrm{ml}^{-1}$ of the acid-treated polysaccharide as tested in an indirect ELISA with $5 \mu \mathrm{g} \mathrm{m}^{-1}$ of immunoreactive polysaccharide fraction coated to the wall of a microtitre plate and expressed as the amount of inhibition remaining.

resides in the neutral sugar side-chains of mucoran, as the $\beta(1-4)$-linked D-glucuronic acid backbone of this polysaccharide was not reactive. The partial acid hydrolysis experiments in which fucose as a 6-deoxy-type sugar was hydrolysed preferentially, indicated that the fucose residues may play an important role in the epitopes. More detailed analysis of this fraction should be performed to elucidate the structure of these epitopes. Specific enzymes can be valuable for this purpose as recently shown by Van Bruggen-van der Lugt et al. (1992).

Apparently, different carbohydrate residues are immunoreactive with the rabbit-raised monospecific pAbs and mouse-raised mAbs. This can be attributed either to the different immunization procedures used or to different host animal species. Intrasplenic immunization was used for raising $\mathrm{mAb} 12.8$ in mice. It can be assumed that in this particular case the species difference might be the major factor for the difference in immune response.

As mAb 12.8 was highly specific for moulds belonging to the order Mucorales, it may be used to develop diagnostic assays for the detection of these species. $\mathrm{mAb}$ based immunoassays may be very useful to monitor mould contamination in food production processes and to monitor fungal spoilage. With this $\mathrm{mAb}$ it may be feasible to test raw materials, food and feed in industrial control laboratories and food inspection services for the presence of moulds belonging to the genera Mucor, Rhizopus, Rhizomucor, Absidia, Thamnidium and Syncephalastrum (De Ruiter et al., 1993b). Furthermore, in medicine these assays may be useful for diagnosis of mucormycosis in humans, by detection of circulating antigens (Kaufman et al., 1989).

We gratefully acknowledge Dr H. J. Kamphuis (Gerkens Cacao Industrie, Wormer, The Netherlands) for carrying out some initial screening experiments and critical reading of the manuscript; $\mathrm{Dr}$ G. Keizer (Holland Biotechnology, Leiden, The Netherlands) for valuable discussions about the dot-blot assay and about the manuscript; and Dr W. Gams and Dr R. A. Samson (Centraalbureau voor Schimmelcultures, Baarn, The Netherlands) for providing some of the strains of moulds used in this study and critical reading of the manuscript. The investigations were supported by the Netherlands' Foundation for Chemical Research (SON) with financial aid from The Netherlands' Technology Foundation (STW).

\section{References}

BARTNICKI-GARCÍA, S. \& LINDBERG, B. (1972). Partial characterization of mucoran: the glucuronomannan component. Carbohydrate Research 23, 75-85.

BartNicki-García, S. \& ReYes, E. (1968). Polyuronides in the cell walls of Mucor rouxii. Biochimica et Biophysica Acta 170, 54-62.

Bos, E. S., Van der Doelen, A. A., Van Rooy, N. \& SchuUrs, A. H. W. M. (1981). 3,3',5,5'-tetramethylbenzidine as an Ames test negative chromogen for horse-radish peroxidase in enzymeimmunoassay. Journal of Immunoassay 2, 187-203.

Bossi, R. \& DEwEY, F. M. (1992). Development of a monoclonal antibody-based immunodetection assay for Botrytis cinerea. Plant Pathology 41, 472-482.

Davis, J. M., Pennington, J. E., Kubler, A. M. \& Conscience, J. F. (1982). A simple, single-step technique for selecting and cloning hybridomas for the production of monoclonal antibodies. Journal of Immunological Methods 50, 161-171.

De Rutter, G. A., Smid, P., VAN der Lugt, A. W., Van Boom, J. H., Notermans, S. H. W. \& Rombouts, F. M. (1991 a). Immunogenic extracellular polysaccharides of Mucorales. In Fungal Cell Wall and Immune Response, NATO ASI Series vol. H 53, pp. 169-180. Edited by J.-P. Latgé \& D. Boucias. Berlin \& Heidelberg: Springer Verlag.

De Ruiter, G. A., VAN DER Lugt, A. W., Voragen, A. G. J., Rombouts, F. M. \& Notermans, S. H. W. (1991 b). High-performance size-exclusion chromatography and ELISA detection of extracellular polysaccharides from Mucorales. Carbohydrate Research 215, 47-57.

De Ruter, G. A., Hoopman, T., Van der Lugt, A. W., Notermans, S. H. W. \& Nout, M. J. R. (1992a). Immunochemical detection of Mucorales species in food. In Modern Methods in Food Mycology, pp. 221-227. Edited by R. A. Samson, A. D. Hocking, J. I. Pitt \& A. D. King. Amsterdam: Elsevier.

De Ruiter, G. A., Josso, S. L., Colquhoun, I. J., Voragen, A. G. J. \& RombouTs, F. M. (1992b). Isolation and characterization of $\beta(1-4)-$ D-glucuronans from extracellular polysaccharides of moulds belonging to Mucorales. Carbohydrate Polymers 18, 1-7.

De Ruiter, G. A., Schols, H. A., Voragen, A. G. J. \& Rombouts, F. M. $(1992 c)$. Carbohydrate analysis of water-soluble uronic acidcontaining polysaccharides with high-performance anion-exchange chromatography using methanolysis combined with TFA hydrolysis is superior to four other methods. Analytical Biochemistry 207, 176-185.

De Ruiter, G. A., Van Bruggen-van der Lugt, A. W., Nout, M. J. R., Middelhoven, W. J., Soentoro, P. S. S., Notermans, S. H. W. \& Rombouts, F. M. (1992d). Formation of antigenic extracellular polysaccharides by selected strains of Mucor spp., 
Rhizopus spp., Rhizomucor spp., Absidia corymbifera and Syncephalastrum racemosum. Antonie van Leeuwenhoek 62, 189-199.

De Ruiter, G. A., Van Bruggen-van der Lugt, A. W., Rombouts, F. M. \& GaMs, W. (1993a). Approaches to the classification of the Mortierella isabellina group (Mucorales): antigenic extracellular polysaccharides. Mycological Research 97, 690-696.

De Ruiter, G. A., Notermans, S. H. W. \& Rombouts, F. M. (1993b). Review: new methods in food mycology. Trends in Food Science and Technology 4, 91-97.

De St Groth, S. F. \& Scheidegger, D. (1980). Production of monoclonal antibodies: strategy and tactics. Journal of Immunological Methods 35, 1-21.

DEWEY, F. M. (1992). Detection of plant-invading fungi by monoclonal antibodies. In Techniques for the Rapid Detection of Plant Pathogens, pp. 47-62. Edited by J. M. Duncan \& L. Torrance. Oxford: Blackwell Scientific Publications.

Dewey, F. M., MacDonald, M. M., Phillips, S. I. \& Priestley, R. A. (1990). Development of monoclonal-antibody-ELISA and -DIP-stick immunoassays for Penicillium islandicum in rice grains. Journal of General Microbiology 136, 753-760.

Kaufman, L., Turner, L. F. \& McLaughlin, D. W. (1989). Indirect enzyme-linked immunosorbent assay for zygomycosis. Journal of Clinical Microbiology 27, 1979-1982.

Miyazaki, T., Yadomae, T., Yamada, H., Hayashi, O., Suzuki, I. \& OHSHIMA, Y. (1980). Immunochemical examination of the polysaccharides of Mucorales. In Fungal Polysaccharides, ACS Symposium Series no. 126, pp. 81-94. Edited by P. A. Sandford \& K. Matsuda. Washington DC: American Chemical Society.
Notermans, S. \& Heuvelman, C. J. (1985). Immunological detection of moulds in food by using the enzyme-linked immunosorbent assay (ELISA); preparation of antigens. International Journal of Food Microbiology 2, 247-258.

Notermans, S., Veeneman, G. H., Van ZuYlen, C. W. E. M., HoOgerhout, P. \& VAN BoOM, J. H. (1988). ( $1 \rightarrow 5$ )-linked $\beta$-Dgalactofuranosides are immunodominant in extracellular polysaccharides of Penicillium and Aspergillus species. Molecular Immunology 25, 975-979.

PitT, J. I. \& Hocking, A. D. (1985). Fungi and Food Spoilage. Sydney: Academic Press.

SPITZ, M. (1986). 'Single-shot' intrasplenic immunization for the production of monoclonal antibodies. Methods in Enzymology 121, $33-41$.

Steinbuch, M. \& Audran, R. (1969). The isolation of IgG from mammalian sera with the aid of caprylic acid. Archives of Biochemistry and Biophysics 134, 279-284.

Stynen, D., Sarfati, J., Goris, A., Prévost, M.-C., Lesourd, M., KAMPHUIS, H., DaRRAS, V. \& LATGÉ, J.-P. (1992). Rat monoclonal antibodies against Aspergillus galactomannan. Infection and Immunity 60, 2237-2245.

Sugar, A. M. (1992). Mucormycosis. Clinical Infectious Disease 14 (Suppl 1), S126-129.

Van BrugGen-van der lugt, A. W., Kamphuis, H. J., De Ruiter, G. A., Mischnick, P., Van Boom, J. H. \& Rombouts, F. M. (1992). New structural features of the antigenic extracellular polysaccharides of Penicillium and Aspergillus species revealed with exo- $\beta$-Dgalactofuranosidase. Journal of Bacteriology 174, 6096-6102. 